\title{
Inverse correlation between high body mass index and response to cholecalciferol treatment in children with vitamin $\mathrm{D}$ deficiency
}

\author{
Sahar Masoumi-Moghaddam', Samar Masoumi-Moghaddam², Seyed Alinaghi Kazemi', \\ Saeideh Mazloomzadeh ${ }^{3}$, Ahmad Jalilvand', Ziba Molaei ${ }^{1,4}$ \\ 'Department of Paediatrics, Mousavi Hospital, Zanjan University of Medical Sciences, Zanjan, Iran \\ ${ }^{2}$ Alfred Hospital, Central Clinical School, Monash University, Melbourne, Australia \\ ${ }^{3}$ Department of Epidemiology and Statistics, School of Medicine, Zanjan University of Medical Sciences, Zanjan, Iran \\ ${ }^{4}$ Metabolic Disease Research Centre, Zanjan University of Medical Sciences, Zanjan, Iran
}

\section{ABSTRACT}

\begin{abstract}
Aim of the study: An inverse correlation between excessive body weight and response to cholecalciferol in vitamin D deficiency (VDD) has been reported but no adjusted or conventional dose and treatment period has universally been recommended by the paediatric guidelines for obese children. In this study, we explored the efficacy of vitamin D supplementation in treatment of children with VDD based on their body mass index (BMI) and different levels of initial serum 25(OH)D.

Material and methods: In a single-centre, prospective, open label non-randomized trial in 255 subjects, baseline serum $25(\mathrm{OH}) \mathrm{D}$ was measured and different doses of oral $\mathrm{D} 3$ prescribed accordingly. Serum $\mathrm{D}_{3}$ was measured at the end of the treatment period. All statistical analyses were conducted using the statistical package SPSS and $\mathrm{p}$ values less than 0.05 considered statistically significant.

Results: The response rate to vitamin D supplementation was associated with the patients' BMI characteristics. $25(\mathrm{OH}) \mathrm{D}$ levels normalized in $97.7 \%$ and $92.7 \%$ of the non-obese and obese subjects, respectively. In subjects with $\mathrm{BMI} \geq 85^{\text {th }}$ percentile, there was a lower increase in vitamin D levels after treatment than those with a BMI $<85^{\text {th }}$ percentile. Evaluating the efficacy of the therapeutic dosage of cholecalciferol as per different categories of vitamin D levels, we observed the highest increase in the level of serum $\mathrm{D}_{3}$ in the severely deficient $\mathrm{D}_{3}$ category of both obese and non-obese groups.

Conclusions: There is an inverse correlation between high Body Mass Index and response to treatment with vitamin D supplementation, suggesting a higher dose of vitamin D for the optimal treatment of vitamin D deficiency in obese children.
\end{abstract}

KEY WORDS:

body mass index, children, cholecalciferol, vitamin $\mathrm{D}$ deficiency.

\section{INTRODUCTION}

Vitamin D deficiency (VDD) is a common problem worldwide with a markedly higher prevalence in the Middle East [1]. This is explained in part by limited sun exposure as a result of cultural practices and dress codes, skin colour, climate, genetic disposition, and insufficiently revisited regulation and guidelines for prevention and treatment of VDD [2]. As a major public health problem across all life stages with deleterious immediate and latent health consequences, VDD does not spare the paediatric age group $[3,4]$.

\section{ADDRESS FOR CORRESPONDENCE:}

Ziba Molaei, Department of Paediatrics, Mousavi Hospital, Zanjan University of Medical Sciences, Zanjan,

Iran, e-mail: zmolaei@zums.ac.ir 
An inverse association has been reported between hypovitaminosis D and obesity, likely due to the increased degradation of vitamin $\mathrm{D}_{3}$ in the adipose tissue of obese individuals, hence its decreased bioavailability $[5,6]$. However, obese people do not necessarily experience lower levels of serum vitamin D. Compensatory hyperparathyroidism and obesity-induced changes in bone metabolism were demonstrated to raise the level of vitamin $\mathrm{D}$ and/or its derivatives in a small number of obese subjects $[7,8]$. The association between vitamin $\mathrm{D}$ insufficiency and obesity has been extensively investigated in adults, resulting in recommendation of higher dose of vitamin D for treatment of VDD in obese adults [9]. However, overweight children seem to receive inadequate attention. There are no universally recommended treatment protocols or widely-used paediatric guidelines with adjustments considered for the treatment of VDD in obese children.

Limited studies have suggested higher doses of vitamin $\mathrm{D}$ for the treatment of obese children with VDD. In a study on African-American children, it was revealed that vitamin $\mathrm{D}_{3}$ supplementation with 400 IU per day for one month did not increase its serum level [10]. In another study on African-American adolescents, usage of 50,000 IU vitamin D supplementation, once a week for 6-8 weeks was found to be effective only in non-obese individuals $[11,12]$. The aim of the present study was to assess the response to vitamin $\mathrm{D}_{3}$ supplementation in children with VDD based on their BMI.

\section{MATERIAL AND METHODS}

\section{PARTICIPANTS}

After reviewing the medical records of 2500 children referred to the paediatric clinic from Jan 2019 to September 2020, 550 cases aged 2-10 years with known serum vitamin $\mathrm{D}$ test results entered the study through subsequent consultation at the Paediatric Endocrine Clinic. Age- and sex-specific BMI percentiles were determined from the 2000 Center for Disease Control (CDC) growth charts. Serum levels of 25-hydroxyvitamin D [25(OH)D] were measured at the reference laboratory using a CDI kit. Subjects were considered non-obese if BMI was between the $5^{\text {th }}$ and $84^{\text {th }}$ percentile, overweight if BMI fell between 85 to 94 percentiles, and obese if BMI equates or exceeds $95^{\text {th }}$ percentile for age and gender. Hereafter, any subject with $\mathrm{BMI} \geq 85^{\text {th }}$ percentile is referred to as obese. The study was carried out between October 2019 and September 2020. Patients were evenly distributed throughout the four seasons. Exclusion criteria were: ongoing multivitamin supplementation; dietary calcium intake exceeding $1500 \mathrm{mg} /$ day; use of an anticonvulsant; systemic glucocorticoid or vitamin D supplements; presence of signs of puberty; hepatic, renal, endocrine or hypothalamic disease; malabsorptive disorder; disorder of bone or calcium metabolism; cancer or genetic disorder that predisposes to obesity. Research protocol was approved by the Institutional Review Board (reference number: 1395.233 ZUMS.REC). Written informed consents and assents were obtained from the parents or guardians of the children who served as subjects of the investigation. The procedures followed were in accordance with the ethical standards of the responsible committee on human experimentation and with the Helsinki Declaration.

\section{STUDY DESIGN}

This study was a prospective open label non-randomized pre-post comparison of the efficacy of vitamin D supplementation in children based on their BMI. Sufficient vitamin D status was defined as $25(\mathrm{OH})$ D level of $\geq 30 \mathrm{ng} / \mathrm{ml}$, whereas VDD was considered as a $25(\mathrm{OH}) \mathrm{D}$ level of $<20 \mathrm{ng} / \mathrm{ml}$, and vitamin $\mathrm{D}$ insufficiency as a 25(OH)D level of 20-29 ng/ml. Children with serum vitamin D levels of $<10 \mathrm{ng} / \mathrm{ml}, 10-19 \mathrm{ng} / \mathrm{ml}$ and 20-29 $\mathrm{ng} / \mathrm{ml}$ were prescribed in total 12,10 , and 6 pearls of vitamin $\mathrm{D}_{3}$ (Zahravi Pharmaceutical), respectively, to take one pearl (50,000 IU) per week.

All subjects received the same compounded vitamin $\mathrm{D}_{3}$ tablets, and compliance was assessed at regular follow-ups by counting the number of pills remaining in the pill bottle. The level of $25(\mathrm{OH}) \mathrm{D}$ was retested by the same laboratory two weeks after completion of the treatment.

\section{STATISTICAL ANALYSIS}

All statistical analyses were conducted using the statistical package SPSS, version 22 (SPSS Inc., USA). Descriptive analysis was used to describe the data either as mean \pm standard deviation (SD) for quantitative variables or frequency (percentage) for categorical variables. Chi square test, independent $t$-test and Mann-Whitney $\mathrm{U}$ test were performed for comparing the actual difference between variables. All calculated $p$-values were twosided, with $\mathrm{p}$ values less than 0.05 considered statistically significant.

\section{RESULTS}

550 children consisting of $56.2 \%$ girls and $43.8 \%$ boys were recruited and divided into two study groups as per the settings criteria: $75.3 \%$ non-obese with a BMI $<85^{\text {th }}$ and $24.7 \%$ obese with $\mathrm{BMI} \geq 85^{\text {th }}$ percentile. With an average age of 7 years in total, the mean $( \pm S D)$ age was $6.49 \pm 2.65$ and $7.40 \pm 2.19$ years in the obese and non-obese groups, respectively. While 121 children (22.0\%) were found to have normal or high levels of vitamin D, 78\% of individuals (45.1\% female and $32.9 \%$ male) were initially diagnosed with VDD or insufficiency, among whom $22.7 \%$ were obese. The overall 
TABLE 1. Baseline characteristics of initial 550 participants

\begin{tabular}{|c|c|c|c|c|}
\hline Characteristics/Categorization & Patients number (\%) & Obese & Non-obese & $P$-value \\
\hline \multicolumn{5}{|l|}{ Age (years) } \\
\hline $2-10$ years & 550 & $6.49 \pm 2.65$ & $7.40 \pm 2.19$ & $<0.0001$ \\
\hline \multicolumn{5}{|l|}{ Sex } \\
\hline Male & $241(43.8)$ & $45(18.7 \%)$ & $196(81.3 \%)$ & \multirow[t]{2}{*}{0.004} \\
\hline Female & $309(56.2)$ & $91(29.4 \%)$ & $218(70.6 \%)$ & \\
\hline \multicolumn{5}{|l|}{ Season } \\
\hline Spring & $131(23.8)$ & $31(23.7 \%)$ & $100(76.3 \%)$ & \multirow[t]{4}{*}{0.649} \\
\hline Summer & $174(31.6)$ & $45(25.9 \%)$ & $129(74.1 \%)$ & \\
\hline Autumn & $110(20.0)$ & $31(28.2 \%)$ & $79(71.8 \%)$ & \\
\hline Winter & $135(24.5)$ & $29(21.5 \%)$ & $106(78.5 \%)$ & \\
\hline \multicolumn{5}{|l|}{ Vitamin D status } \\
\hline$<10 \mathrm{ng} / \mathrm{ml}$ & $57(10.4)$ & $15(26.3 \%)$ & $42(73.68 \%)$ & \multirow[t]{5}{*}{$<0.0001$} \\
\hline $10-19.9 \mathrm{ng} / \mathrm{ml}$ & $188(34.2)$ & $59(31.3 \%)$ & $129(68.62 \%)$ & \\
\hline $20-29.9 \mathrm{ng} / \mathrm{ml}$ & $184(33.5)$ & $51(27.7 \%)$ & $133(72.28 \%)$ & \\
\hline $30-99.9 \mathrm{ng} / \mathrm{ml}$ & $112(20.4)$ & $11(9.82 \%)$ & $101(90.18 \%)$ & \\
\hline$\geq 100 \mathrm{ng} / \mathrm{ml}$ & $9(1.6)$ & 0 & $9(100 \%)$ & \\
\hline
\end{tabular}

Values are presented as mean $\pm S D$

TABLE 2. Baseline characteristics in 255 vitamin D-deficient, compliant participants

\begin{tabular}{|c|c|c|c|c|}
\hline Characteristics/categorization & Patients number (\%) & Obese & Non-obese & $P$-value \\
\hline \multicolumn{5}{|l|}{ Age (years) } \\
\hline $2-10$ years & 255 & $7.40 \pm 2.18$ & $6.65 \pm 2.54$ & 0.013 \\
\hline \multicolumn{5}{|l|}{ Sex } \\
\hline Male & $99(38.8)$ & $44(35.8 \%)$ & $55(41.7 \%)$ & \multirow[t]{2}{*}{0.369} \\
\hline Female & $156(61.2)$ & $79(64.2 \%)$ & $77(58.3 \%)$ & \\
\hline \multicolumn{5}{|l|}{ Season } \\
\hline Spring & $57(22.4)$ & $29(50.9 \%)$ & $28(49.1 \%)$ & \multirow[t]{4}{*}{0.802} \\
\hline Summer & $82(32.2)$ & $37(45.1 \%)$ & $45(54.9 \%)$ & \\
\hline Autumn & $57(22.4)$ & $30(52.6 \%)$ & 27 (47.4\%) & \\
\hline Winter & $59(23.1)$ & $27(45.8 \%)$ & $32(54.2 \%)$ & \\
\hline \multicolumn{5}{|l|}{ Vitamin D status } \\
\hline$<10 \mathrm{ng} / \mathrm{ml}$ & $34(13.3)$ & $15(12.2 \%)$ & $19(14.4 \%)$ & \multirow[t]{3}{*}{0.542} \\
\hline $10-19.9 \mathrm{ng} / \mathrm{ml}$ & $109(42.7)$ & $57(46.3 \%)$ & $52(39.4 \%)$ & \\
\hline $20-29.9 \mathrm{ng} / \mathrm{ml}$ & $112(43.9)$ & $51(41.5 \%)$ & $61(46.2 \%)$ & \\
\hline
\end{tabular}

Values are presented as mean \pm SD

prevalence of VDD and insufficiency $(<30 \mathrm{ng} / \mathrm{ml})$ was $78 \%$ with $22.72 \%$ in obese subjects and $55.27 \%$ in nonobese subjects. 74 (13.45\%) of the obese subjects and $171(31.1 \%)$ of the non-obese subjects were vitamin D deficient $(<20 \mathrm{ng} / \mathrm{ml})$. Table 1 shows the baseline characteristics of these 550 candidates.

Patients with vitamin D levels greater than $30 \mathrm{ng} / \mathrm{ml}$ and those found to be non-compliant with their medication or follow-ups were excluded and the study continued with 255 patients. Of these, $51.8 \%$ and $48.2 \%$ were non- obese and obese, respectively. The mean baseline $25(\mathrm{OH})$ $\mathrm{D}$ level was higher in the non-obese subjects compared to the obese subjects (mean, $26.82 \pm 1.07$ vs. $20.15 \pm 0.82$, $p=0.001) .41 .5 \%$ of obese subjects and $46.2 \%$ of nonobese subjects had vitamin D level in the $20-29.9 \mathrm{ng} / \mathrm{ml}$ range. $72(58.5 \%)$ of the obese subjects and $71(53.8 \%)$ of the non-obese subjects were vitamin $\mathrm{D}$ deficient $(<20 \mathrm{ng} / \mathrm{ml})$. As shown in Table 2 , the distribution of sex, season and initial levels of vitamin D in the obese and non-obese groups was not statistically different. 
TABLE 3. The correlation of baseline vitamin D with patients' characteristics

\begin{tabular}{|c|c|c|c|c|}
\hline Categorization & $<10 \mathrm{ng} / \mathrm{ml}$ & $10-19.9 \mathrm{ng} / \mathrm{ml}$ & $20-29.9 \mathrm{ng} / \mathrm{ml}$ & P-value \\
\hline Sex & & & & 0.26 \\
\hline Male & $9(26.5)$ & $43(39.3)$ & $47(42.0)$ & \\
\hline Female & $25(73.5)$ & $66(60.6)$ & $65(58.0)$ & \\
\hline BMI & & & & 0.53 \\
\hline$<85^{\text {th }}$ percentile & $19(55.9)$ & $52(47.7)$ & $61(54.5)$ & \\
\hline$\geq 85^{\text {th }}$ percentile & $15(44.1)$ & $57(52.3)$ & $51(45.5)$ & \\
\hline
\end{tabular}

Values are presented as mean $\pm S D$

Considering the correlation of baseline vitamin $\mathrm{D}$ with patients' characteristics (Table 3), no significant difference in the mean serum level of vitamin $\mathrm{D}$ was found between boys and girls prior to the treatment $(p$-value $=0.22)$. Among those with severe VDD $(<10 \mathrm{ng} / \mathrm{ml})$, girls comprised the majority $(73.5 \%)$ when compared to boys (26.5\%). The correlation between the initial level of vitamin $\mathrm{D}$ and children's BMI was found insignificant $(p=0.74)$.

Following the treatment, all cases demonstrated a marked increase in their serum levels of vitamin $\mathrm{D}$, irrespective of their BMI and initial vitamin D grouping (the mean pre-treatment level: $18.20 \pm 6.6 \mathrm{ng} / \mathrm{ml}$ vs. post-treatment level: $59.90 \pm 23.0 \mathrm{ng} / \mathrm{ml}, p<0.0001)$. Nevertheless, in only $89.4 \%$ of children the improved level of vitamin D fell within the normal range. $25(\mathrm{OH}) \mathrm{D}$ levels normalized (> $30 \mathrm{ng} / \mathrm{ml}$ ) in $129(97.7 \%)$ of the non-obese subjects, compared to $114(92.7 \%)$ of the obese subjects. Serum vitamin $\mathrm{D}$ remained below the normal range in $4.7 \%$ of subjects, consisting of $3(25 \%)$ of the non-obese and $9(75 \%)$ of the obese subjects. Toxic levels of vitamin D $(>100 \mathrm{ng} / \mathrm{ml})$ were recorded in $5.8 \%$ of treated children, among whom one child was obese and 14 children were in the non-obese group. Of these 14 children, 9 had an initial vitamin D level between 20 and 30ng/ml, 2 had it between 10 and $20 \mathrm{ng} / \mathrm{ml}$, and 3 had it below $10 \mathrm{ng} / \mathrm{ml}$. The mean level of vitamin D after treatment was not statistically different between boys and girls ( $p$-value: 0.36). Moreover, no correlation between different categories of post-treatment vitamin D levels and gender was indicated ( $p$-value: 0.48 ).

Contrary to the insignificant correlation of the initial level of vitamin D and BMI, the effectiveness of response to vitamin D supplementation was found to be affected by the patients' BMI characteristics. Following the completion of treatment, the mean serum level of vitamin $\mathrm{D}$ was $69.3 \pm 25.3 \mathrm{ng} / \mathrm{dl}$ and $49.8 \pm 14.6 \mathrm{ng} / \mathrm{ml}$ in the $\mathrm{BMI}<85^{\text {th }}$ and $\geq 85^{\text {th }}$ percentile groups, respectively $(p<0.001)$ showing a lower increase in the post-treatment vitamin D levels in the obese group (Table 4).

\section{DISCUSSION}

In this study, we compared response to cholecalciferol treatment in obese and non-obese Caucasian mid-
TABLE 4. Pre- and post-treatment serum vitamin D according to the BMI

\begin{tabular}{|c|c|c|c|}
\hline \multirow{2}{*}{ Categorization } & \multicolumn{2}{|c|}{ Serum vitamin D level } & \multirow{2}{*}{ P-value } \\
\cline { 2 - 3 } & Pre-treatment & Post-treatment & \\
\hline$<85^{\text {th }}$ percentile & & & $<0.001$ \\
\hline$<10 \mathrm{ng} / \mathrm{ml}$ & $7.5 \pm 1.5$ & $63.5 \pm 30.2$ & \\
\hline $10-19.9 \mathrm{ng} / \mathrm{ml}$ & $15.3 \pm 3.1$ & $64.5 \pm 25.3$ & \\
\hline $20-29.9 \mathrm{ng} / \mathrm{ml}$ & $24.2 \pm 2.7$ & $75.3 \pm 22.7$ & \\
\hline$\geq 85^{\text {th }}$ percentile & & & $<0.001$ \\
\hline$<10 \mathrm{ng} / \mathrm{ml}$ & $7.3 \pm 2.2$ & $44.4 \pm 24.9$ & \\
\hline $10-19.9 \mathrm{ng} / \mathrm{ml}$ & $17.3 \pm 2.7$ & $47.3 \pm 12.7$ & \\
\hline $20-29.9 \mathrm{ng} / \mathrm{ml}$ & $29.9 \pm 2.0$ & $54.1 \pm 11.8$ & \\
\hline
\end{tabular}

Values are presented as mean $\pm S D$

dle-eastern children aged 2-10 years who were diagnosed with VDD. While the overall response to vitamin D supplementation was acceptable in the studied subjects with $89.4 \%$ of them showing a normalized vitamin D level, the overall response to treatment was approximately 1.4fold lower in obese group as compared to the non-obese one. This finding is in line with a previous study demonstrating an inverse correlation between BMI and either peak serum vitamin $\mathrm{D}_{2}$ or $\mathrm{D}_{3}$ concentrations following a single oral dose of 50,000 IU of vitamin $\mathrm{D}_{2}$ or UV-B irradiation in adolescence, likely due to the decreased bioavailability of vitamin $\mathrm{D}_{3}$ as a result of its deposition in body fat compartments [8]. Poor response to vitamin $\mathrm{D}_{2}$ or $\mathrm{D}_{3}$ supplementation has also been reported in other studies. Castaneda et al. showed that the increment in $25(\mathrm{OH}) \mathrm{D}$ levels following vitamin D supplementation was significantly lower in the obese adolescents, thus higher doses of vitamin $\mathrm{D}$ are required to treat VDD in obese adolescents than in their non-obese peers [13]. A negative correlation between vitamin D levels and BMI, BMI percentiles, waist and hip circumference was also reported by Bellone et al. in children [14]. Moreover, body mass index has been shown to have a significant effect on serum $25-(\mathrm{OH}) \mathrm{D}$ levels, as well as the dose of vitamin $\mathrm{D}_{3}$ in white [15] and African-American menopausal women [16]. Gallagher et al. showed that treating obese and non-obese individuals with the same dosage of vitamin $\mathrm{D}_{3}$ resulted in a lower response rate in obese subjects. In 
accordance with this, a retrospective study of vitamin $\mathrm{D}$ deficient Hispanic and African American adolescents who were treated with weekly vitamin D supplementation (50,000 IU for 6-8 weeks) demonstrated that only a subset of subjects could reach normalized $25(\mathrm{OH}) \mathrm{D}$. They thus suggested that increased surveillance and possibly higher vitamin D doses are warranted for obese adolescents [12]. A similar observation was made by Ashraf et al. when they prospectively studied obese African American female adolescents receiving ergocalciferol (vitamin $\mathrm{D}_{2}$ ) 50,000 IU for 8 weeks. The increment of the serum $25(\mathrm{OH}) \mathrm{D}$ concentration was noted in only two thirds of the participants [11]. In another study by Mazahery et al. in premenopausal Middle-Eastern women, lower body fat percentage as well as a larger dose appeared to be significantly influencing a better response to oral vitamin D supplementation [17]. They reported that one unit decrease in body fat (\%) resulted in a $0.7 \mathrm{nmol} / \mathrm{l}$ increase in serum-25(OH)D. Chung et al studied an eightweek course of vitamin D replacement (2,000 IU/day) and reported normalization in $61.9 \%$ and $47.6 \%$ of normal-weight and overweight children, respectively, without a statistically significant difference in the mean serum $25(\mathrm{OH}) \mathrm{D}$ levels following treatment in those groups [18]. Although the exact mechanism for a poorer response is yet unknown, this might be secondary to difference in vitamin D metabolism in obese group or a possible greater degree of sequestration of lipid-soluble vitamin D in the adipose tissue [19].

In our study, participants were instituted with three different doses of vitamin $\mathrm{D}_{3}$ as per their initial serum vitamin $\mathrm{D}$ concentrations. With a desirable response rate in the entire cohort, the toxic serum levels of vitamin D were observed in 15 children, consisting of only one obese case who received a total of 6 pearls. The majority of non-obese children (9 out of 14) with toxic serum levels of $\mathrm{D}_{3}$ were found to be prescribed the minimum dosage ( 6 pearls) of vitamin D. "Considering both the lower response rate and toxicity rate in obese children, it seems sensible that higher doses of vitamin $\mathrm{D}$ would be required for the treatment of obese children. The total amount of vitamin $\mathrm{D}$ received by our patients ranged from a minimum of 300,000 (6 pearl, each 50,000 ) to a maximum of 600,000 UI (12 pearl, each 50,000 UI). To the best of our knowledge, this is the first report of such treatment adjustments where high dosage of oral vitamin $\mathrm{D}$ are prescribed for different time periods based on the initial serum level of vitamin $\mathrm{D}$ and consideration of the possible toxicity ensuing".

In a similar study, Motlaghzadeh et al. prescribed the whole cohort with 6 pearls of vitamin D3 in total (50000 IU/week for 6 weeks) but the normalization rate of $25(\mathrm{OH}) \mathrm{D} 3$, in particular in obese children was lower than that in our study [20]. When Gabi et al. commenced obese patients on an intramuscular vitamin $\mathrm{D}_{3}$ of 300,000 to 600,000 units, only $35 \%$ got normal level of vitamin D
[21]. Rajakumar et al. treated vitamin $\mathrm{D}_{3}$ deficient subjects with 400 units of vitamin $\mathrm{D}_{3}$ daily for 1 month but this was found inadequate [10]. A 24-week treatment with weekly vitamin $\mathrm{D}_{2} 50,000$ IU by Samaranayake et al. was also reported inadequate as the mean vitamin $\mathrm{D}$ levels did not rise above the deficiency cut-off value of $20 \mathrm{ng} / \mathrm{ml}$ [22].

The Institute of Medicine (IOM) recommended dietary allowance for vitamin D is $600 \mathrm{IU}$ daily for healthy population aged 1-18 years in order to maintain the recommended level for serum 25(OH)D ( $\geq 50 \mathrm{nmol} / \mathrm{l})$. However, there is disagreement between recommendations of the American Academy of Pediatrics (AAP) and Endocrine Society guidelines who recommend lower and higher dosage than that of 600 IU for the same age group, respectively [23]. When it comes to deficiency, while the AAP recommends 5,000 IU per day, the Endocrine Society guidelines recommend 50,000 IU weekly of vitamin D for at least 6 weeks or until serum concentrations of $25(\mathrm{OH}) \mathrm{D}$ are above $50 \mathrm{nmol} / \mathrm{l}$. Although these dosages are found to be well tolerated, there is no evidence if the maintenance dosage can be similar in nonobese and obese as the obese are approximately half as efficient in using vitamin D compared to their non-obese counterparts. In light of the above, a separate set of guidelines for obese adolescents is warranted [23].

Although the relationship between obesity and vitamin D status is clear in the adult population, there is no consensus on the literature regarding a higher frequency of vitamin D deficiency in children and adolescents with obesity. In our study, the correlation between the primary level of vitamin D and children's BMI was found insignificant. According to previous studies, the prevalence of VDD seems to be related to obesity level and BMI, being expected to be higher in overweight and obese children [24]. However, in our study, $22.7 \%$ of cases diagnosed with hypovitaminosis D were obese and the rest were children with normal BMI. While some studies have indicated a higher prevalence of VDD in obese children $[14,25,26]$, others describe this linkage insignificant. Rajakumar et al. reported that while VDD occurred in $57 \%$ obese vs. $40 \%$ non-obese subjects who were matched for age, sex, skin colour, and pubertal maturation, the difference was not statistically significant [10]. A study by Dura-Trave et al found that $25(\mathrm{OH}) \mathrm{D}$ levels in children with obesity were inversely associated with body fat content, and this association was stronger than that between 25(OH)D and BMI or body weight [27]. They indicated that obesity increases the prevalence of suboptimal vitamin D status, and a BMI status reduction in children with obesity may be required to at least stabilize vitamin D status. In a meta-analysis study, the relative risk for the association between VDD and obesity in children was lower compared to in adults (1.41 vs. 3.43) [28]. However, high heterogeneity was seen in all studies with regard to the different cut-off points for $25(\mathrm{OH}) \mathrm{D}$ defi- 
ciency, the severity of obesity and multifactorial aetiology of hypovitaminosis $\mathrm{D}$ as possible confounding factors in the analysis.

In the current study, treatment-response effects were different between obese and non-obese groups with regard to different threshold levels of serum 25(OH)D ranging from severely deficient to just insufficient levels. Evaluating the efficacy of the therapeutic dosages of prescribed cholecalciferol as per different categories of vitamin D levels, the difference was more prominent in the severely deficient as well as insufficient vitamin D patients. The highest increase in the level of serum vitamin $D_{3}$ after treatment was seen in the severely deficient $\mathrm{D}_{3}$ category of both obese and non-obese group. The association between treatment response and basal $25(\mathrm{OH}) \mathrm{D}$ thresholding in obese group was consistent with a previous study reporting that treatment was effective in the obese cohort for those with basal $25(\mathrm{OH}) \mathrm{D} \leq 20 \mathrm{ng} / \mathrm{ml}$ [10]. In the present study, among the children who had serum vitamin D levels of $<10 \mathrm{ng} / \mathrm{ml}$ and received weekly $\mathrm{D}_{3} 50,000 \mathrm{IU}$ for a period of 12 weeks, the non-obese cases showed 8.5-fold increment in the $25(\mathrm{OH}) \mathrm{D}$ levels but the change was only 6 -fold in the obese group (1.4fold lower in the obese group). The raise in the serum $25(\mathrm{OH}) \mathrm{D}_{3}$ level following the treatment with 6 pearls of vitamin $\mathrm{D}_{3} 50,000 \mathrm{IU}$ was 1 .3-fold lower in the obese group as cases in the $<85^{\text {th }}$ percentile reached a 3.1 -fold increase in their serum vitamin $\mathrm{D}$ level versus an only 1.8 -fold increase in the $\geq 85^{\text {th }}$ group. These findings suggest that the efficacy of cholecalciferol treatment is correlated with the BMI and partly with the severity of hypovitaminosis $\mathrm{D}$ in the obese children. To our knowledge, this is the first study that has examined the impact of obesity itself, without any other confounding variables such as ethnicity, gender or season, on response to different doses of vitamin $\mathrm{D}_{3}$ supplementation in Caucasian Middle Eastern children. We conclude that the threshold levels of primary serum $25(\mathrm{OH}) \mathrm{D}$ associates with response to vitamin $\mathrm{D}$ therapy in obese and non-obese children, potentially due to differences in the metabolism of $25(\mathrm{OH}) \mathrm{D}$ and a greater degree of sequestration of vitamin D in the body fat deposits of obese children. However, further assessment is warranted in a larger cohort.

Evaluating the association of primary vitamin D level and gender, no significant difference in prevalence was observed between girls and boys with regard to the mean serum 25(OH)D. This was in accordance with Gordon et al. findings in which the prevalence of VDD was $26.0 \%$ vs. 20.6 in girls and boys, respectively [25]. Inclusion of serum $\mathrm{D}_{3}$ level thresholding, however, resulted in girls to be defined as the majority of severe vitamin D deficient cases in our study. This was consistent with some previous studies reporting girls to have higher prevalence of VDD than boys [29, 30]. Studying 68 obese adolescents, Harel et al. reported that the prevalence of low vitamin D status was $100 \%$ in obese girls and $91 \%$ in obese boys. About
$72 \%$ of the females were vitamin deficient and $28 \%$ were vitamin insufficient, whereas $69 \%$ of the males were vitamin D deficient, 22\% were vitamin D insufficient, and 9\% had sufficient vitamin D status [12]. Variation in physical activity and cultural differences, including difference in clothing style and coverage among boys and girls may partly justify this difference.

\section{CONCLUSIONS}

In this study, we observed that the response of vitamin-D deficient obese children to the recommended high-dose intermittent vitamin D therapy as per the Endocrine Society guidelines was significantly lower than that of non-obese individuals. In addition, stratification of obese and non-obese patients with VDD based on different cut-offs of initial serum vitamin D showed different response rates in the cohort. Determination of the proper dosage of vitamin D in children with VDD according to their initial serum levels of D3 and BMI is warranted in a larger study.

\section{DISCLOSURE}

The authors declare no conflict of interest.

\section{REFERENCES}

1. El-Hajj Fuleihan G. Vitamin D Deficiency in the Middle East and Its Health Consequences. In: Holick MF (ed.). Vitamin D: Physiology, Molecular Biology, and Clinical Applications. Humana Press, Totowa 2010; 469-494.

2. Soliman AT, De Sanctis V, Elalaily R, et al. Vitamin D deficiency in adolescents. Indian J Endocrinol Metab 2014; 18: S9-S16.

3. Holick MF. Vitamin D deficiency. N Engl J Med 2007; 357: 266281.

4. Unuvar T, Buyukgebiz A. Nutritional rickets and vitamin D deficiency in infants, children and adolescents. Pediatr Endocrinol Rev 2010; 7: 283-291.

5. Alemzadeh R, Kichler J, Babar G, Calhoun M. Hypovitaminosis D in obese children and adolescents: relationship with adiposity, insulin sensitivity, ethnicity, and season. Metab Clinical Exp 2008; 57: 183-191.

6. Smotkin-Tangorra M, Purushothaman R, Gupta A, et al. Prevalence of vitamin D insufficiency in obese children and adolescents. J Pediatr Endocrinol Metab 2007; 20: 817-823.

7. Hyldstrup L, Andersen T, McNair P, et al. Bone metabolism in obesity: changes related to severe overweight and dietary weight reduction. Acta Endocrinol (Copenh) 1993; 129: 393-398.

8. Wortsman J, Matsuoka LY, Chen TC, et al. Decreased bioavailability of vitamin D in obesity. Am J Clin Nutr 2000; 72: 690-693.

9. Holick MF, Binkley NC, Bischoff-Ferrari HA, et al. Evaluation, treatment, and prevention of vitamin D deficiency: an Endocrine Society clinical practice guideline. J Clin Endocrinol Metab 2011; 96: 1911-1930.

10. Rajakumar K, Fernstrom JD, Holick MF, et al. Vitamin D status and response to Vitamin D(3) in obese vs. non-obese African American children. Obesity (Silver Spring) 2008; 16: 90-95. 
11. Ashraf AP, Alvarez JA, Gower BA, et al. Associations of serum 25-hydroxyvitamin $\mathrm{D}$ and components of the metabolic syndrome in obese adolescent females. Obesity (Silver Spring) 2011; 19: 2214-2221.

12. Harel Z, Flanagan P, Forcier M, Harel D. Low vitamin D status among obese adolescents: prevalence and response to treatment. J Adolesc Health 2011; 48: 448-452.

13. Aguirre Castaneda R, Nader N, Weaver A, et al. Response to vitamin D3 supplementation in obese and non-obese Caucasian adolescents. Horm Res Paediatr 2012; 78: 226-231.

14. Bellone S, Esposito S, Giglione E, et al. Vitamin D levels in a paediatric population of normal weight and obese subjects. J Endocrinol Invest 2014; 37: 805-809.

15. Gallagher JC, Sai A, Templin T, et al. Dose Response to Vitamin D Supplementation in Postmenopausal Women: A Randomized Trial. Ann Inter Med 2012; 156: 425-437.

16. Gallagher JC, Peacock M, Yalamanchili V, et al. Effects of vitamin D supplementation in older African American women. J Clin Endocrinol Metab 2013; 98: 1137-1146.

17. Mazahery H, Stonehouse W, von Hurst PR. The effect of monthly $50,000 \mathrm{IU}$ or $100,000 \mathrm{IU}$ vitamin D supplements on vitamin D status in premenopausal Middle Eastern women living in Auckland. Eur J Clin Nutr 2015; 69: 367-372.

18. Chung IH, Kang YS, Yoo E-G. Response to vitamin D replacement in overweight and normal weight children with vitamin D deficiency. Ann Pediatr Endocrinol Metab 2019; 24: 22-26.

19. Bell NH, Epstein S, Greene A, et al. Evidence for alteration of the vitamin D-endocrine system in obese subjects. J Clin Invest 1985; 76: 370-373.

20. Motlaghzadeh Y, Sayarifard F, Allahverdi B, et al. Assessment of Vitamin D Status and Response to Vitamin $\mathrm{D}_{3}$ in Obese and NonObese Iranian Children. J Trop Pediatr 2016; 62: 269-275.

21. Gheibi S, Nikibakhsh AA, Goshaderou R. Evaluation the Response to Treatment of Vitamin D Deficiency in Iranian Overweight/obese Children. Int J Pediatr 2016; 4: 1305-1313.

22. Samaranayake D, Adikaram SGS, Atapattu N, et al. Vitamin D supplementation in obese Sri Lankan children: a randomized controlled trial. BMC Pediatrics 2020; 20: 426.

23. Peterson C. Vitamin D deficiency and childhood obesity: interactions, implications, and recommendations. Nutrition and Dietary Supplements 2015; 7: 29-39.

24. Zakharova I, Klimov L, Kuryaninova V, et al. Vitamin D Insufficiency in Overweight and Obese Children and Adolescents. Front Endocrinol 2019; 10: 103.

25. Gordon CM, DePeter KC, Feldman HA, et al. Prevalence of Vitamin D Deficiency Among Healthy Adolescents. Arch Pediatr Adolesc Med 2004; 158: 531-537.

26. Olson ML, Maalouf NM, Oden JD, et al. Vitamin D deficiency in obese children and its relationship to glucose homeostasis. J Clin Endocrinol Metab 2012; 97: 279-285.

27. Durá-Travé T, Gallinas-Victoriano F, Chueca-Guindulain MJ, et al. Assessment of vitamin D status and parathyroid hormone during a combined intervention for the treatment of childhood obesity. Nutr Diab 2019; 9: 18.

28. Fiamenghi VI, Mello ED. Vitamin D deficiency in children and adolescents with obesity: a meta-analysis. J Pediatr (Rio J) 2021; 97: 273-279.

29. Alaklabi AM, Alsharairi NA. Current Evidence on Vitamin D Deficiency and Metabolic Syndrome in Obese Children: What Does the Evidence from Saudi Arabia Tell Us? Children (Basel, Switzerland) 2018; 5: 11 .

30. Mansbach JM, Ginde AA, Camargo CA, Jr. Serum 25-hydroxyvitamin D levels among US children aged 1 to 11 years: do children need more vitamin D? Pediatrics 2009; 124: 1404-1410. 